\title{
Resenhas
}

\section{RECIPROCIDAde E COMPREENSÃo da LeITURA}

\section{Oczukus, L. D. (2003). Reciprocal teaching at work: strategies for improving reading comprehension. Newark: IRA, 216 p.}

Em 1984, Palincsar e Brown desenvolveram e testaram quatro estratégias de ensino-recíproco para auxiliar o desenvolvimento da compreensão em leitura. Muitas pesquisas e estudos foram feitos e entre os estudiosos neste campo está Lori D. Oczkus que elaborou o livro aqui resenhado. A obra compreende: introdução, quatro capítulos, conclusão e três apêndices, além das referências (atuais, pertinentes), índice de autores e conteúdo, o que facilita a consulta de assuntos específicos e a releitura de tópicos especiais.

$\mathrm{Na}$ Introdução, a autora retoma o ensino recíproco de forma global, sua base científica, descreve sua experiência e explicita a razão de ter elaborado o presente livro. Apresenta o formato dado a cada um dos capítulos que introduzem variações no uso da reciprocidade. Todos compreendem uma descrição do ambiente, os objetivos de ensino recíproco, a organização para o trabalho, uma perspectiva geral, as opções de avaliação. Lista os aspectos das estratégias em cada caso incluindo: denominação, ambiente e descrição, materiais, modelagem pelo professor, participação do aluno e tipos de avaliação. Cada capítulo apresenta um resumo e questões para auto-estudo, grupos de estudo e desenvolvimento da equipe.

O capítulo 1 traz as quatro estratégias do ensino recíproco: prever, questionar, clarificar e resumir. Também apresenta algumas barreiras que o professor pode encontrar ao usar estas estratégias e faz sugestões para solucionar os problemas. Por exemplo, se o professor não está seguro sobre como verificar o progresso ao aluno, poderá observar as respostas do aluno, pedir que o aluno responda por escrito individualmente usando cada estratégia. Mostra a necessidade de dar e de retirar apoio, pensar em voz alta, aprendizagem cooperativa como formas de dar apoio ao aluno.
No capítulo seguinte, é descrito o uso do ensino recíproco aplicado na classe como um todo. Neste caso, os objetivos são: estabelecer uma linguagem comum na classe; aumentar as oportunidades para ensinar e apoiar usando as estratégias, guiar os estudantes de todos os níveis para melhorarem a compreensão, mostrar aos alunos como usar muitas estratégias para compreender a ler; envolver em discussão de compreensão e fornecer um formato comunitário de reforçamento e procedimento para leitura em grupo ou círculos literários. O tema continua no capítulo 3 em que é enfocada mais especificamente a orientação de grupos de leitura. Aborda estratégias como a revisão de textos familiares para a melhoria da fluência e da compreensão; revisão de textos escolhidos usando gráficos organizadores; revisão de textos usando ilustrações, gráficos, títulos, subtítulos; leitura seguida de uso de estratégias recíprocas para discussão e responder e refletir sobre os próprios pensamentos e sentimentos durante a leitura.

Ensino recíproco nos círculos literários é o título do capítulo seguinte. $\mathrm{O}$ uso das estratégias recíprocas nestes círculos melhora a compreensão, pois oferece mais oportunidades de participação, cooperação, apoio, motivação, uso de metacognição e independência. Os círculos literários podem ser organizados em sala de aula ou fora dela, antes de serem constituídos é preciso treinar os participantes nas estratégias do ensino recíproco, desenvolver habilidades sociais e domínio de procedimentos específicos. O porquê e o como modelar e ensinar estes comportamentos são considerados no texto. Também trata de como avaliar o desempenho e competência dos alunos apresentando fichas de registro de grande utilidade.

Todos os capítulos são enriquecidos com exemplos de aulas planejadas usando as estratégias e quadros que apresentam sínteses úteis na releitura e consulta a parte específica do trabalho. Nas conclusões, destaca a 
necessidade de comprovar se os alunos estão realmente aprendendo e responde sucintamente às 16 questões mais comuns sobre esta forma de ensinar. Fecha o texto estimulando o uso do ensino recíproco.

O primeiro apêndice é constituído por um roteiro para observação dos alunos durante o ensino-aprendizagem. O segundo é um instrumento de auto-avaliação para uso do aluno. O último é um instrumento informal de avaliação-entrevista.

Além de tratar de tema atual, apresenta de forma clara e precisa como funciona o ensino recíproco. $\mathrm{O}$ livro traz instrumentos e sugestões para a pesquisa. É assunto pouco divulgado e conhecido nos meios educacionais brasileiros, merecendo maior divulgação pelo seu potencial de resolução dos muitos problemas educacionais vivenciados no Brasil. Seria relevante pesquisar esta concepção de ensino-aprendizagem no Brasil já que tem se mostrado muito eficiente.

Geraldina Porto Witter UMC/PUC-Campinas 